\section{Root Applications of Gibberellic Acid Enhance Growth of Seven Pelargonium Cultivars}

\author{
Richard N. Arteca ${ }^{1}$, Carl D. Schlagnhaufer ${ }^{2}$, and \\ Jeannette M. Arteca ${ }^{3}$ \\ Department of Horticulture, The Pennsylvania State University, \\ University Park PA 16802 \\ Additional index words. gibberellic acid, $\mathrm{GA}_{3}$, Pelargonium $\times$ hortorum, $P$. \\ $\times$ domesticum
}

\begin{abstract}
Four concentrations of $\mathrm{GA},\left(0.05,0.5,5.0\right.$, or $\left.50 \mathrm{mg} \cdot \mathrm{liter}^{-1}\right)$ were applied to the root systems of seven hydroponically grown geranium (Pelargonium $\times$ hortorum Cv. Empress Irene, Glacier Crimson, Sincerity, Pink Fiat, Sybil Holmes, and Mrs. Parker and $P . \times$ domesticum $\mathrm{Cv}$. Lavender Grand Slam) cultivars. The relative growth rate of all cultivars tested increased with $\mathrm{GA}_{3}$ treatments. In conjunction with the increase in growth rate, each of the cultivars showed a reduction in the root : shoot ratio and chlorophyll content per unit leaf area with no change in the percent moisture. These Pelargonium cultivars are genetically diverse, showing that $\mathbf{G A}_{3}$ can stimulate growth over a wide range of cultivars. Chemical name used: gibberellic acid $\left(\mathbf{G A}_{3}\right)$.
\end{abstract}

Foliar applications of $\mathrm{GA}_{3}$ have been reported to either increase (Bidwell and Turner, 1966) or have no effect (Little and Loach, 1975) on photosynthetic rates. Previous research has shown that a single $\mathrm{GA}_{3}$ treatment to the roots of hydroponically grown tomato plants can stimulate photosynthesis and plant growth (Artea and Dong, 1982). Similar GA treatments increased photosynthesis, relative growth rate, and cutting production of two geranium cultivars, regardless of whether they normally grew rapidly or slowly (Arteca et al., 1985). The purpose of this study was to determine if a $\mathrm{GA}_{3}$ treatment to the roots would stimulate growth and development in seven Pelargonium cultivars.

Culture-virus-indexed callused cuttings of Pelargonium $\times$ hortorum cvs. Empress Irene, Glacier Crimson, Sincerity, Pink Fiat,

Received for publication 11 Dec. 1990. This work was supported by the Pennsylvania State Univ. Agricultural Experiment Station Project no. 2809, Oglevee Associates, and the American Floral Endowment. This is contribution no. 136 of the Dept. of Horticulture, The Pennsylvania State Univ., and is authorized for publication as no. 8062 in the Journal Series of the Pennsylvania Agricultural Experiment Station. The cost of publishing this paper was defrayed in part by the payment of page charges. Under postal regulations, this paper therefore must be hereby marked advertisement solely to indicate this fact.

'Associate Professor.

${ }^{2}$ Postdoctoral Scholar.

${ }^{3}$ Senior Research Aide.
Sybil Holmes, and Mrs. Parker and P. domesticum cv. Lavender Grand Slam were obtained commercially (Oglevee Associates, Connellsville, Pa.). They were rooted in onefourth-strength Hoagland solution (Hoagland and Arnon, 1938) under continual aeration and subsequently grown under 14-h days (25C) and 10-h nights (20C) at a photosynthetic photon flux of $300 \mu \mathrm{mol} \cdot \mathrm{s}^{-1} \cdot \mathrm{m}^{-2}$. Following the 2-week rooting period, $\mathrm{GA}_{3}$ was added directly to the nutrient solution to obtain concentrations of $0,0.05,0.50,5.0$, or $50.0 \mathrm{mg} \cdot$ liter $^{-1}$. Growth was measured after 4 days of treatment. Each treatment had four single-plant replications, and each experiment was repeated three times. The data from all experiments were pooled for presentation, and regression analysis was performed.

Relative growth rates (RGR) were calculated from the total plant fresh weight recorded when treated and again 4 days later according to the procedure outlined by Collins (1976). At this point, the plants were harvested and the root : shoot ratios determined by separating the roots from stems, petioles, and leaves, followed by fresh weight determination of each. The percent moisture was determined by taking an initial weight, drying the plants at $80 \mathrm{C}$, and calculating the percent change (dry weight/wet weight $\times$ 100). Chlorophyll was determined according to the procedure described by Witham et al. (1971).

Chlorophyll content was reduced by $\mathrm{GA}_{3}$ treatments in all cultivars when expressed on an area basis (Fig. 1), but not on a freshweight basis (data not shown). There were no changes in the percent moisture content in any of the cultivars in response to $\mathrm{GA}_{3}$ treatments (data not shown); however, there was an overall increase in total plant weight. The Pelargoniums tested represent a wide range of cultivars, showing that root treatments with $\mathrm{GA}_{3}$ can effectively and broadly stimulate growth (Fig. 2). This result concurs with other work (Arteca et al., 1985), showing that root applications promote an increase in RGR and enhance the production

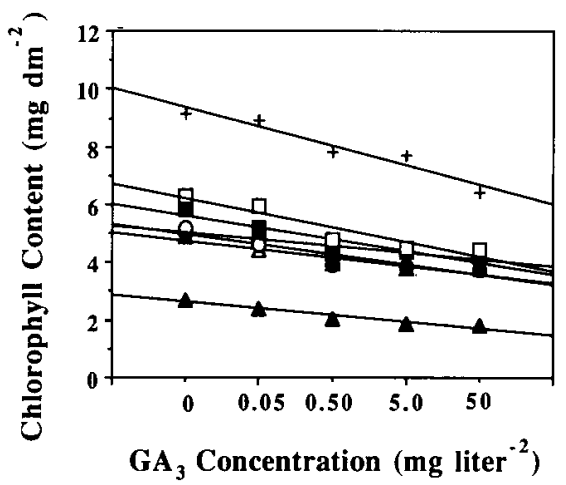

Fig. 1. Regression analysis of the effects of varying concentrations of $\mathrm{GA}_{3}$ on chlorophyll content of Pelargonium $\times$ hortonum cv. Empress Irene $(\bullet)\left(R^{2}=0.879\right)$, Glacier Crimson (D) $\left(R^{2}=0.836\right)$, Mrs. Parker $(\Lambda)\left(R^{2}=\right.$ $0.951)$, Pink Fiat $(\triangle)\left(R^{2}=0.877\right)$, Sincerity $(\square)\left(R^{2}=0.877\right)$, and Sybil Holmes $(+)\left(R^{2}\right.$ $=0.929)$ and $P . \times$ domesticum cv. Lavender Grand Slam $(O)\left(R^{2}=0.823\right)$.

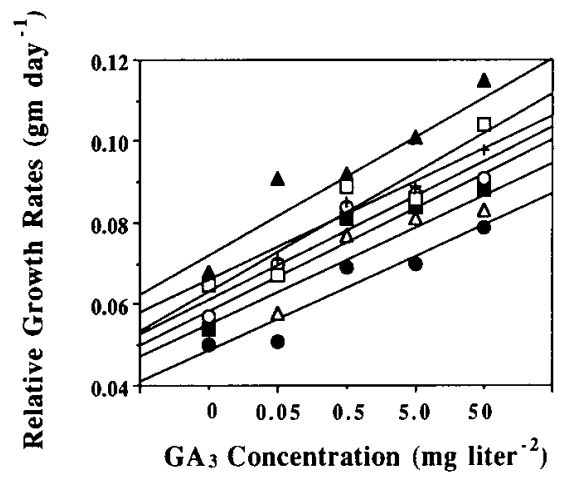

Fig. 2. Regression analysis of the effects of varying concentrations of $\mathrm{GA}_{3}$ on relative growth rate of Pelargonium $\times$ hortorum cv. Empress Irene ( $\bullet)\left(R^{2}=0.911\right)$, Glacier Crimson $(\boldsymbol{\square})$ $\left(\mathrm{R}^{2}=0.909\right)$, Mrs. Parker $(\boldsymbol{\Delta})\left(R^{2}=0.919\right)$, Pink Fiat $(\Delta)\left(R^{2}=0.885\right)$, Sincerity $(\square)\left(R^{2}\right.$ $=0.885)$, and Sybil Holmes $(+)\left(R^{2}=0.970\right)$ and $P . \times$ domesticum cv. Lavender Grand Slam ( O ) $\left(R^{2}=0.914\right)$. 


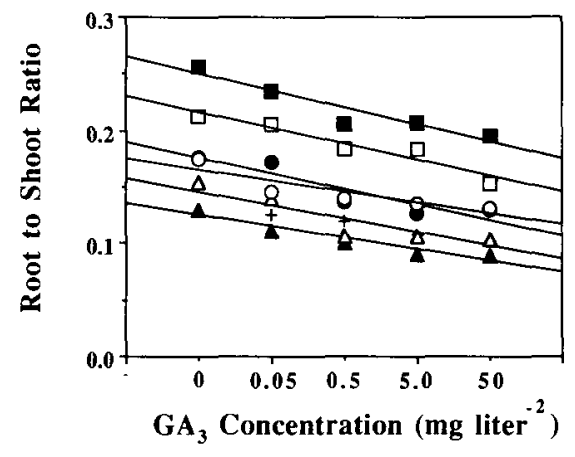

Fig. 3. Regression analysis of the effects of varying concentrations of $\mathrm{GA}_{3}$ on root : shoot ratio of Pelargonium $\times$ hortorum cv. Empress Irene ( $)\left(R^{2}=0.846\right)$, Glacier Crimson $(\mathbf{\square})$ $\left(\mathrm{R}^{2}=0.892\right)$, Mrs. Parker $(\boldsymbol{\Delta})\left(\mathrm{R}^{2}=0.913\right)$, Pink Fiat $(\Delta)\left(\mathrm{R}^{2}=0.832\right)$, Sincerity $(\square)\left(R^{2}\right.$ $=0.921)$ and Sybil Holmes $(+)\left(R^{2}=0.900\right)$ and $P . \times$ domesticum $\mathrm{cv}$. Lavender Grand Slam ( O ) $\left(R^{2}=0.803\right)$. of cuttings in two Pelargonium cultivars. Our current results also show that $\mathrm{GA}_{3}$ promoted a general decrease in the root : shoot ratio (Fig. 3), suggesting that the $\mathrm{GA}_{3}$-induced increase in RGR was not due to an increase in photosynthetic activity. Instead, it was probably due to a modification in normal partitioning of photosynthate (Little and Loach, 1975). All cultivars treated with $\mathrm{GA}_{3}$ were visibly larger than nontreated plants. We also observed that the leaves of all cultivars treated with $\mathrm{GA}_{3}$ were more flexible than nontreated plants, which could possibly reduce damage during shipping and handling operations.

We conclude that root applications of $\mathrm{GA}_{3}$ have much potential for enhancing cutting production in geraniums, yielding plants less apt to be damaged during shipping and benefits that may possibly apply to other species as well.

\section{Literature Cited}

Arteca, R.N. and C.N. Dong. 1982. Increase photosynthetic rates following gibberellic acid treatments to the roots of tomato plants. Photosynthesis Res. 2:243-249.

Arteca, R. N., E.J. Holcomb, C.D. Schlagnhaufer, and D.S. Tsai. 1985. Effects of root applications of gibberellic acid on photosynthesis, transpiration, and growth of geranium plants. HortScience 20:925-927.

Bidwell, R.G.S. and W.B. Turner. 1966. Effect of growth regulators on $\mathrm{CO}_{2}$ assimilation in leaves and its correlation with the bud break response in photosynthesis. Plant Physiol. 41:257-270

Collins, W.B. 1976. Effect of carbon dioxide enrichment on growth of the potato plant. HortScience 11:467-469.

Hoagland, D.R. and D.I. Arnon. 1938. The waterculture method for growing plants without soil. Univ. of California Agr. Expt. Circ. 347.

Little, C.H.A. and K. Loach. 1975. Effect of gibberellic acid on growth and photosynthesis in Abies balsamea. Can. J. Bet. 53:1805-1810.

Witham, F. H., D.F. Blaydes, and R.N. Devlin. 1971. Experiments in plant physiology. van Nostrand, New York. 